\title{
Yield Performances of Tomatoes (Lycopersicum esculentum) on Organic Manure Buffered Lateritic Soils
}

\author{
*1'LAMIDI, WA; ${ }^{1}$ SHITTU, KA; ${ }^{2}$ ADEYEYE, AS \\ ${ }^{I}$ Department of Agronomy' College of Agriculture, Ejigbo, Osun State University, Osogbo, Nigeria \\ ${ }^{2}$ Department of Crop Production and Protection, Faculty of Agriculture and Life Sciences, Federal University, Wukari, Taraba State, \\ Nigeria \\ *Correspondence Email Address: wasiu.agunbiade@uniosun.edu.ng
}

\begin{abstract}
Lateritic soils are found in many farms even though they have not been known to be encouragingly productive to farmers because of their non-supportive of agricultural products. This experiment was to help farmers whose lands are lateritic to produce more crops/ha when buffered with organic manure. There were six treatments namely: laterite soil, laterite soil buffered with organic manure, laterite soil buffered with NPK 15-15-15, sandy loam soil, sandy loam soil buffered with organic manure (OM) and sandy loam soil buffered with NPK 15-15-15. There were three replicates for each treatments, the arrangement was $2 \times 6 \times 3$ factorial design of 36 pots, parameters measured during the experiment were days to emergency, days to flowering, days to fruiting, number of branches, number of fruits per plant, nodes and internodes, stem girth length, leaf length of plant, plant height (from the surface of the soil to the apex (tip) of the plant) at twice a week and number of leaves per plant counted and recorded each week. The whole arrangements were subjected to the same environmental and climatic conditions. Chemical and physical characteristics of the soil in different treatments were done in the laboratory before and after. The data collected were subjected to two-way ANOVA. The results revealed that seed germination percentage was higher in sandy-loam buffered soil, $92.5 \%$, followed by lateritic buffered soil $87.5 \%$. Statistical analysis showed statistical differences among the yield and yield parameters for types of soil. However, the growth parameters taken as height, number of leaves, fresh and dry weight were found to be higher in sandy-loam soil followed by laterite soil and finally alluvium soil. Statistical analysis of these also showed significant differences between the types of soil used. Laterite buffered soil could yield as high as sandy loam soil in the production of tomatoes.
\end{abstract}

\section{DOI: https://dx.doi.org/10.4314/jasem.v22i8.10}

Copyright: Copyright $\odot 2018$ Lamidi et al. This is an open access article distributed under the Creative Commons Attribution License (CCL), which permits unrestricted use, distribution, and reproduction in any medium, provided the original work is properly cited.

Dates: Received: 12 June 2018; Revised: 01 August: 2018; Accepted: 13 August 2018

Keywords: buffered laterite, number of leaves, sandy-loam, soil factors

Tomato plants typically grow to 1-3 metres in height and have a weak stem that often sprawls over the ground and vines over other plants. It is grown in both tropical and temperate climates; it does well in welldrained soil found some parts of Nigeria (Tindall, 1998). Although there is a considerable potential for increased tomato production, numerous factors limit yields (Mulatu and Lakew, 2011). The most important abiotic stresses include low soil fertility, low soil pH, poor soil drainage, drought and poor agronomic practices. The expansion of tomato production in Nigeria has been accomplished by the establishment of numerous vegetable processing industries, although the production level in the country is still far behind as most are consumed by buying raw from market. The establishment of both private and government network of dams and irrigation facilities, especially in Northern Nigeria have greatly enhanced the production of tomato in Nigeria (Quinn, 2003; Quinn, 1999). Poor soil fertility is a major constraint to agricultural productivity, where population and livestock pressure is high (Zelleke et al., 2010; Agegnehu et al., 2014a).
Chemical fertilizer application has been limited to date, and improvement of agricultural productivity necessitates more than the application of chemical fertilizers alone. Soil differs greatly in texture, chemical composition, colour, depending upon the particles size of mineral component and the amount of organic matter present. Laterite is a soil layer that is rich in iron oxide and derived from a wide variety of rocks weathering under strongly oxidizing and leaching conditions. It forms in tropical and subtropical regions where the climate is humid. Lateritic soils may contain clay minerals; but they tend to be silica-poor, for silica is leached out by waters passing through the soil. Typical laterite is porous and claylike. It is best used in road, buildings and dam constructions being product from rock that is a response to a set of physiochemical conditions. These conditions include an iron-containing parent rock, a well-drained terrain and abundant moisture for hydrolysis during weathering, relatively high oxidation potential, and persistence of these conditions over thousands of years. Lateritic soils are one of 
important soils and are widespread in tropical areas and subtropical climates. They are the most highly weathered soils in the classification system. The significant features of the lateritic soils are their unique color, poor fertility, and high clay content and lower cation exchange capacity. In addition, lateritic soils possess a great amount of iron and aluminum oxides (Shaw, 2001; Ko, 2008; Ko et al., 2006). Parent material is a key factor affecting the iron and mineral composition and distribution for lateritic soils. Anda et al. (2008) reported a series of oxisols derived from serpentinite, basalt, and andesite and found that the content of iron oxides has an obvious different distribution.

Laterite is not uniquely identified with any particular parent rock, geologic age, single method of formation, climate per se, or geographic location. Since it can be found anywhere due to where it is produced from, it is good to be researched upon if it will readily support plant growth. Tomatoes, being delicate plant could be appropriate for such. There have been many options of agricultural systems that have been used in the area. Amelioration of subsoil horizons by using cover crops whose roots have the potential to drill into impermeable regions for nutrients' absorption (Chen and Well, 2010; Chen et al., 2008), also known as biological drilling to create favorable soil structure for subsequent row crops to explore (Cresswell and Kirkegaard, 1995). This affects both macro- and micro-porosity depending on whether coarse or fine roots are involved (Bodner et al., 2014). Also, inclusion of clover as a cover crop to enhance yield in a compacted sandy loam soil and the response was attributed to the effects of the organic mulch combined with root drilling (Stirzaker et al., 1996). Lateritic soils are found in Ejigbo and environs especially in Afaake, Isudurin, Ilawo and its other adjoining villages. These lands may be made available and capable of to yield more per acre when buffered, thus the research was postulated. The research focused on the performances of lateritic soils when mixed with organic manure to be able to make the more available farmable land to the farmers in the area.

\section{MATERIALS AND METHODS}

Sample area and collection: This study was carried out in the Teaching and Research Farms of Osun State University, Ejigbo Campus, Osun State. The soils used were laterite and sandy loam, both soils were buffered and were also used as control. Buffering materials used were organic manure (OM) made from compost and inorganic fertilizers namely NPK 15-15-15 weighed at the rate of $4 \mathrm{~kg}$ mixed thoroughly per soil sample in each pot (calculated from $200 \mathrm{~kg} / \mathrm{ha}$ rate for each of the pot as per its soil volume).
Sample preparation and treatment: There were six treatments namely: laterite soil, laterite soil buffered with organic manure, laterite soil buffered with NPK 15-15-15, sandy loam soil, sandy loam soil buffered with organic manure (OM) and sandy loam soil buffered with NPK 15-15-15. There were three replicates for each treatment, the arrangement was $2 \times$ $6 \times 3$ factorial design of 36 pots. Tomato seeds were subjected to viability test to differentiate the viable seeds from non-viable seeds using floating method of transparent plastic container. This method of testing was $95-100 \%$ sure of the seed testing, although depending on the variety or type of seed to be cultivated. Weeding was not encouraged because the seedling could not be identified from the weeds. Sprouting of seedlings commence at different days and rate. Thinning was done to one stand per pot.

Soil Analysis: The soil analysis was conducted at the Agronomy Department Laboratory of Osun State University, College of Agriculture, Ejigbo to determine the mineral/heavy metals analysis of thirty six (36) soil samples. Soil samples were air dried at room temperature, pulverized and pass through the 2 $\mathrm{mm}$ sieve and analyzed using standard procedures. Samples were analyzed for physical and chemical properties for the following parameters: soil $\mathrm{pH}$ was determined in 1:1 soil water suspension using a $\mathrm{pH}$ meter (Hendershot et al., 1993); Particle size distribution was determined by the Bouyoucus hydrometer method using Calgon as a dispersing agent (Gee and Or, 2002).Organic carbon was analyzed by the dichromate oxidation procedures of (Nelson and Sommers, 1996). Total Nitrogen was determined by micro-Kjeldah method (Bremner et al., 1985); Available phosphorus was determined by Bray-1 method, (Anderson and Ingram, 1993); Exchangeable cations were determined extracted using $\mathrm{NH}_{4} \mathrm{OAc}$ buffered at $\mathrm{pH} 7$ (Thomas, 1982). Potassium (K) and Sodium $(\mathrm{Na})$ were determined by a flame photometer while exchangeable Calcium (Ca) and Magnesium $(\mathrm{Mg})$ were determined using Spectrophotometer (AAS) PerkinElmer 403.

Sample analysis: The following morphological parameters were measured during the experiment, days to emergency, days to flowering, days to fruiting, number of branches, number of fruits per plant, nodes and internodes, stem girth length, leaf length of plant, plant height (from the surface of the soil to the apex (tip) of the plant) at twice a week and number of leaves per plant counted and recorded each week. The whole arrangements were subjected to the same environmental and climatic conditions. Chemical and physical characteristics of the soil in different 
treatments were done in the laboratory before and after the experiment to be able to deduce the change if at all in the soil with respective to the outcome of the yield parameters measured.

Statistical analysis: The data collected were subjected to two-way Analysis of Variance (ANOVA) using a statistical package by CoStat (CoHort Software, 2014). Mean values that were significant were separated using least significant difference.

\section{RESULTS AND DISCUSSION}

Seed germination: Sprouting commenced the second week of planting. Some germinated at five days while others germinated seven to eight days as shown with their mean values in Table 1. The first emergency of seedlings brings two cotyledon leaves and looks so small at fifth day for the first week. The results revealed that seed germination percentage was higher in sandy-loam buffered soil, $92.5 \%$, followed by lateritic buffered soil, $87.5 \%$. They were all staked to prevent them from falling and for all the measured parameters to be appropriate. The plants carry different leave numbers and different leaf length.

Physical and chemical properties of the soil: The physico-chemical properties of soil before planting are presented in Table 1, it revealed low values of exchangeable cations, percent organic carbon (\%OC) and OM, however there were slight changes after the buffering in either cases, Table 2 . The increments were due to the buffering with OM and NPK. The soil reaction ranged between slightly acidic (6.91, Laterite non-buffered) and neutral (7.08, sandy loam buffered with OM (Adepetu et al., 2014). The texture ranged between loamy sand to sandy loam. Cation exchange capacity (CEC) was generally low. The soil was deficient in major nutrients; therefore adequate soil amendment was necessary for profitable tomato crop production.

Table 1: Chemical and physical characteristics of different soils before the experiment

\begin{tabular}{|c|c|c|c|c|c|c|}
\hline \multirow[t]{2}{*}{ Soil Parameter } & \multicolumn{6}{|c|}{ Soil types } \\
\hline & $\begin{array}{l}\text { Laterite } \\
\text { non- } \\
\text { buffered }\end{array}$ & $\begin{array}{l}\text { Laterite } \\
\text { buffered } \\
\text { with OM }\end{array}$ & $\begin{array}{l}\text { Laterite } \\
\text { buffered } \\
\text { with NPK }\end{array}$ & $\begin{array}{l}\text { Sandy } \\
\text { loam non- } \\
\text { buffered }\end{array}$ & $\begin{array}{l}\text { Sandy loam } \\
\text { buffered } \\
\text { with OM }\end{array}$ & $\begin{array}{l}\text { Sandy loam } \\
\text { buffered } \\
\text { with NPK }\end{array}$ \\
\hline \multicolumn{7}{|c|}{ Chemical characteristics } \\
\hline $\mathrm{pH}(\mathrm{H} 2 \mathrm{O})$ & 6.91 & 6.97 & 6.92 & 7.00 & 7.08 & 7.00 \\
\hline Organic carbon $(\%)$ & 0.60 & 0.90 & 0.88 & 1.06 & 0.89 & 0.82 \\
\hline Organic matter (\%) & 0.20 & 0.82 & 0.40 & 0.98 & 0.99 & 0.70 \\
\hline Available P (ppm) & 0.85 & 2.18 & 2.58 & 2.58 & 1.52 & 1.50 \\
\hline $\mathrm{CEC},(\mathrm{meg} / 100 \mathrm{~g})$ & 6.50 & 5.36 & 7.50 & 8.10 & 8.26 & 6.30 \\
\hline $\mathrm{K}(\mathrm{ppm})$ & 40.21 & 50.47 & 50.23 & 46.08 & 92.12 & 40.15 \\
\hline $\mathrm{Ca}(\mathrm{ppm})$ & 1.20 & 2.20 & 1.00 & 19.00 & 40.00 & 32.02 \\
\hline $\mathrm{Mg}(\mathrm{ppm})$ & 8.20 & 10.80 & 11.40 & 16.40 & 35.40 & 29.80 \\
\hline Nitrogen(ppm) & 0.13 & 0.18 & 0.37 & 0.28 & 0.72 & 0.52 \\
\hline Sodium (ppm) & 20.12 & 30.23 & 27.30 & 38.58 & 42.33 & 32.50 \\
\hline $\mathrm{Cu}^{3+}(\mathrm{ppm})$ & 0.88 & 1.07 & 2.27 & 1.37 & 1.15 & 1.29 \\
\hline $\mathrm{Mn}^{2-}(\mathrm{ppm})$ & 9.12 & 11.23 & 60.21 & 29.59 & 99.37 & 80.50 \\
\hline $\mathrm{Co}^{3+}(\mathrm{ppm})$ & 0.75 & 1.20 & 1.20 & 1.38 & 0.20 & 4.21 \\
\hline $\mathrm{Fe}^{2-}(\mathrm{ppm})$ & 43.20 & 62.00 & 60.12 & 42.77 & 40.20 & 42.10 \\
\hline $\begin{array}{l}\mathrm{Zn}^{2+}(\mathrm{ppm}) \\
\text { Physical characteri }\end{array}$ & 0.91 & 1.42 & 1.20 & 1.77 & 3.40 & 1.92 \\
\hline $\mathrm{S}$ and $(\mathrm{g} / \mathrm{kg})$ & 881.20 & 474.20 & 808.20 & 700.20 & 640.30 & 800.40 \\
\hline S ilt $(\mathrm{g} / \mathrm{kg})$ & 18.80 & 436.50 & 94.30 & 172.50 & 230.40 & 49.40 \\
\hline Clay $(\mathrm{g} / \mathrm{kg})$ & 100.00 & 89.30 & 93.50 & 127.30 & 129.30 & 150.20 \\
\hline Textural class & $\begin{array}{l}\text { Sandy } \\
\text { clay }\end{array}$ & $\begin{array}{l}\text { S andy } \\
\text { loam clay }\end{array}$ & $\begin{array}{l}\text { Sandy } \\
\text { clay }\end{array}$ & $\begin{array}{l}\text { Sandy } \\
\text { loam }\end{array}$ & $\begin{array}{l}\text { Sandy silt } \\
\text { loam }\end{array}$ & $\begin{array}{l}\text { Sandy silt } \\
\text { loam }\end{array}$ \\
\hline
\end{tabular}

Yield and Yield parameters: The different treatments have significant effects at $p>0.01$ and at $p>0.05$ on the yield parameters of the tomatoes, plant height, number of leaves, leaf area, and number of buds produced, number of nodes and number of internodes produced per week. Others are on the stem girth, fruit weight, fresh fruit weight and number of tomato fruits produced, that is the eventual yield, Table 3 .
However, there was no significant effect of the treatment on the tomatoes' fruit length and fruit breadth, that is, the perimeter of the tomatoes fruits. Coefficient of variation, $\mathrm{CV}$ reveals lower values in all, they were less than 30 , implying the validity of the treatment and the overall design of the experiment. There were statistical differences among the mean values for yield parameters recorded in Table 4 . 
Table 2: Chemical and physical characteristics of different soils after the experiment

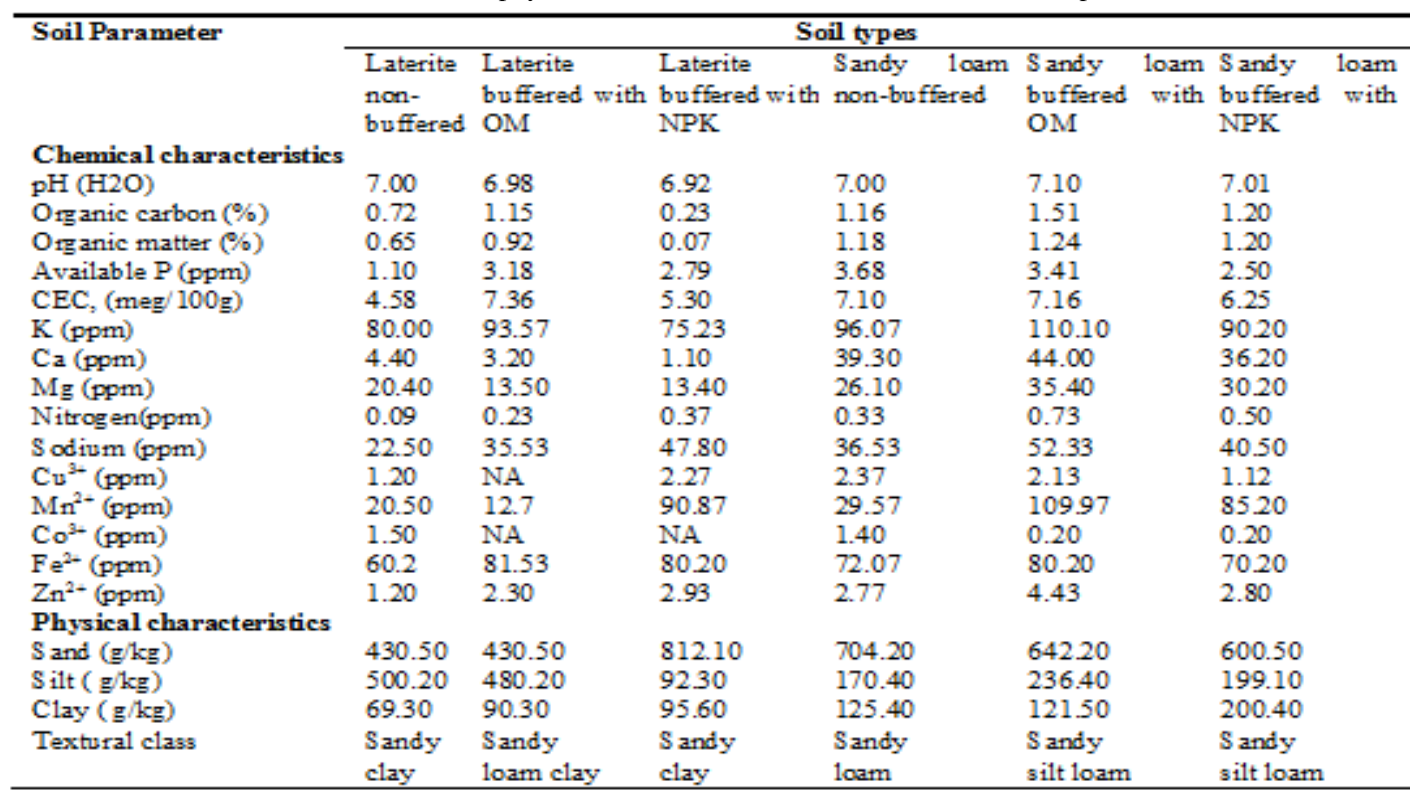

Table 3: Analysis of variance table on tomato

\begin{tabular}{|c|c|c|c|c|c|c|c|}
\hline \multirow{2}{*}{ Yield parameters } & \multicolumn{6}{|c|}{ ANOVA analysis } & \multirow{2}{*}{$\mathrm{CV} \%$} \\
\hline & Block & Soil type & Treatment (Trt) & Soil type $\times$ Trt & Error & Total & \\
\hline Degree of freedom & 2 & 2 & 2 & 4 & 16 & 26 & \\
\hline Plant height, $\mathrm{cm}$ & 1073.76* & $43.01^{\mathrm{ns}}$ & $63.93^{\mathrm{ns}}$ & $24.46^{\mathrm{ns}}$ & $26.60^{\mathrm{ns}}$ & & 11.27 \\
\hline No. of leaves & $520.78^{*}$ & $30.33^{\mathrm{ns}}$ & $10.33^{\mathrm{ns}}$ & $31.33^{\mathrm{ns}}$ & $26.40^{\mathrm{ns}}$ & & 5.45 \\
\hline Leaf area, $\mathrm{m}^{2}$ & $99.20 *$ & $9.54^{\mathrm{ns}}$ & $0.31^{\mathrm{ns}}$ & $6.69^{\mathrm{ns}}$ & $4.89^{\mathrm{ns}}$ & & 25.40 \\
\hline No. of buds & $6.37 *$ & $3.70^{\mathrm{ns}}$ & $2.93^{\mathrm{ns}}$ & $0.48^{\mathrm{ns}}$ & $1.54^{\mathrm{ns}}$ & & 4.19 \\
\hline No. of nodes & $16.33^{*}$ & $0.78^{\mathrm{ns}}$ & $0.11^{\mathrm{ns}}$ & $0.89^{\mathrm{ns}}$ & $0.92^{\mathrm{ns}}$ & & 4.54 \\
\hline No. of internodes & $1.22 *$ & $0.18^{\mathrm{ns}}$ & $0.16^{\mathrm{ns}}$ & $0.03^{\mathrm{ns}}$ & $0.16^{\mathrm{ns}}$ & & 6.60 \\
\hline Stem girth, cm & $1.82 *$ & $0.08^{\mathrm{ns}}$ & $0.08^{\mathrm{ns}}$ & $0.22^{\mathrm{ns}}$ & $0.16^{\mathrm{ns}}$ & & 6.81 \\
\hline Fruit length, cm & $2.37^{\mathrm{ns}}$ & $1.41^{\mathrm{ns}}$ & $2.83^{\mathrm{ns}}$ & $0.32^{\mathrm{ns}}$ & $1.01^{\mathrm{ns}}$ & & 19.89 \\
\hline Fruit breadth, $\mathrm{cm}$ & $5.52^{\mathrm{ns}}$ & $0.62^{\mathrm{ns}}$ & $3.41^{\mathrm{ns}}$ & $3.39^{\mathrm{ns}}$ & $2.96^{\mathrm{ns}}$ & & 20.53 \\
\hline Fruit weight, g & $6.27 *$ & $0.14^{\mathrm{ns}}$ & $0.29^{\mathrm{ns}}$ & $0.21^{\mathrm{ns}}$ & $0.24^{\mathrm{ns}}$ & & 19.93 \\
\hline Fresh fruit weight, $g$ & $15.41 *$ & $1.28^{\mathrm{ns}}$ & $1.94^{\mathrm{ns}}$ & $1.88^{\mathrm{ns}}$ & $2.27^{\mathrm{ns}}$ & & 25.94 \\
\hline No. of fruits & $14.40 *$ & $0.19^{\mathrm{ns}}$ & $0.38^{\mathrm{ns}}$ & $1.17^{\mathrm{ns}}$ & $1.05^{\mathrm{ns}}$ & & 23.18 \\
\hline
\end{tabular}

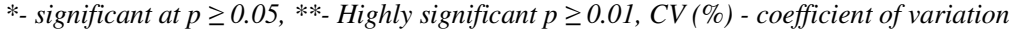

Table 4: Mean values of the yield parameters depicting effects of different treatments on tomato

\begin{tabular}{lllllll}
\hline Yield parameters & $\begin{array}{l}\text { Soil samples } \\
\text { Laterite non- } \\
\text { buffered }\end{array}$ & $\begin{array}{l}\text { Laterite } \\
\text { buffered with } \\
\text { OM }\end{array}$ & $\begin{array}{l}\text { Laterite } \\
\text { buffered with } \\
\text { NPK }\end{array}$ & $\begin{array}{l}\text { Sandy loam } \\
\text { non-buffered }\end{array}$ & $\begin{array}{l}\text { Sandy loam } \\
\text { buffered with } \\
\text { OM }\end{array}$ & $\begin{array}{l}\text { Sandy loam } \\
\text { buffered with } \\
\text { NPK }\end{array}$ \\
\hline Plant height, cm & $43.66^{\mathrm{c}} \pm 2.77$ & $44.90^{\mathrm{ab}} \pm 3.61$ & $47.40^{\mathrm{b}} \pm 2.65$ & $43.29^{\mathrm{c}} \pm 4.37$ & $46.60^{\mathrm{a}} \pm 3.83$ & $48.77^{\mathrm{a}} \pm 4.19$ \\
No. of leaves & $93.78^{\mathrm{c}} \pm 2.49$ & $95.44^{\mathrm{a}} \pm 2.76$ & $95.44^{\mathrm{a}} \pm 2.41$ & $96.11^{\mathrm{a}} \pm 3.60$ & $92.11 \pm 1.89$ & $93.44^{\mathrm{c}} \pm 3.02$ \\
Leaf area, $\mathrm{m}^{2}$ & $8.85^{\mathrm{b}} \pm 1.82$ & $8.49^{\mathrm{b}} \pm 1.17$ & $9.12^{\mathrm{a}} \pm 1.16$ & $9.46^{\mathrm{a}} \pm 1.44$ & $7.53^{\mathrm{c}} \pm 0.89$ & $8.77^{\mathrm{b}} \pm 1.31$ \\
No. of buds & $30.22^{\mathrm{a}} \pm 0.22$ & $29.11^{\mathrm{ab}} \pm 0.54$ & $30.33^{\mathrm{a}} \pm 0.33$ & $29.22^{\mathrm{ab}} \pm 0.59$ & $29.22^{\mathrm{b}} \pm 0.40$ & $29.44^{\mathrm{c}} \pm 0.56$ \\
No. of nodes & $21.11^{\mathrm{ab}} \pm 0.26$ & $21.00^{\mathrm{ab}} \pm 0.55$ & $21.22^{\mathrm{b}} \pm 0.40$ & $20.78^{\mathrm{c}} \pm 0.64$ & $21.33^{\mathrm{a}} \pm 3.33$ & $21.22^{\mathrm{b}} \pm 0.59$ \\
No. of internodes & $5.94^{\mathrm{b}} \pm 0.23$ & $6.20^{\mathrm{a}} \pm 0.11$ & $6.17^{\mathrm{ab}} \pm 0.12$ & $5.89^{\mathrm{ab}} \pm 0.15$ & $6.09^{\mathrm{a}} \pm 0.19$ & $6.00^{\mathrm{ab}} \pm 0.10$ \\
Stem girth, cm & $5.79^{\mathrm{ab}} \pm 0.22$ & $5.73^{\mathrm{ab}} \pm 0.15$ & $5.77^{\mathrm{ab}} \pm 0.16$ & $5.92^{\mathrm{a}} \pm 0.18$ & $5.76^{\mathrm{ab}} \pm 0.21$ & $5.92^{\mathrm{a}} \pm 0.17$ \\
Fruit length, cm & $6.15^{\mathrm{a}} \pm 0.47$ & $4.91^{\mathrm{c}} \pm 0.11$ & $4.91^{\mathrm{c}} \pm 0.16$ & $5.19^{\mathrm{ab}} \pm 0.15$ & $5.10^{\mathrm{ab}} \pm 0.12$ & $5.19^{\mathrm{ab}} \pm 0.13$ \\
Fruit breadth, cm & $9.55^{\mathrm{a}} \pm 0.54$ & $8.34^{\mathrm{ab}} \pm 0.18$ & $8.36^{\mathrm{ab}} \pm 0.24$ & $8.35^{\mathrm{ab}} \pm 0.26$ & $8.42^{\mathrm{ab}} \pm 0.21$ & $8.31^{\mathrm{ab}} \pm 0.22$ \\
Fruit weight, g & $2.80^{\mathrm{a}} \pm 0.00$ & $2.36^{\mathrm{ab}} \pm 0.22$ & $2.48^{\mathrm{ab}} \pm 0.29$ & $2.55^{\mathrm{c}} \pm 0.31$ & $2.36^{\mathrm{ab}} \pm 0.29$ & $2.60^{\mathrm{c}} \pm 0.28$ \\
Fresh fruit weight, g & $5.26^{\mathrm{a}} \pm 0.00$ & $4.22^{\mathrm{ab}} \pm 0.31$ & $4.94^{\mathrm{c}} \pm 0.44$ & $4.43^{\mathrm{ab}} \pm 0.63$ & $4.32^{\mathrm{ab}} \pm 0.46$ & $4.64^{\mathrm{c}} \pm 0.59$ \\
No. of fruits & $6.00^{\mathrm{ab}} \pm 0.00$ & $5.75^{\mathrm{ab}} \pm 0.41$ & $6.11^{\mathrm{b}} \pm 0.54$ & $6.56^{\mathrm{a}} \pm 0.69$ & $5.78^{\mathrm{b}} \pm 0.64$ & $5.90^{\mathrm{c}} \pm 0.71$ \\
\hline
\end{tabular}

Mean values with the same letter(s) along the row are statistically different at $\mathrm{p}>0.01$ and 0.05 
Table 5: Mean values of the fruiting and fruit parameters depicting effects of different treatments

\begin{tabular}{lllllll}
\hline Yield parameters & $\begin{array}{l}\text { Laterite non- } \\
\text { buffered }\end{array}$ & $\begin{array}{l}\text { Laterite } \\
\text { buffered with } \\
\text { OM }\end{array}$ & $\begin{array}{l}\text { Laterite } \\
\text { buffered with } \\
\text { NPK }\end{array}$ & $\begin{array}{l}\text { Sandy loam } \\
\text { non-buffered }\end{array}$ & $\begin{array}{l}\text { Sandy loam } \\
\text { buffered with } \\
\text { OM }\end{array}$ & $\begin{array}{l}\text { Sandy loam } \\
\text { buffered with } \\
\text { NPK }\end{array}$ \\
\hline No. of days to emergency & $6.93^{\mathrm{a}} \pm 0.22$ & $6.13^{\mathrm{ab}} \pm 0.12$ & $6.72^{\mathrm{b}} \pm 0.2$ & $6.97^{\mathrm{b}} \pm 0.19$ & $5.20^{\mathrm{c}} \pm 0.22$ & $6.20^{\mathrm{ab}} \pm 0.53$ \\
No. of Stalk lodged & $8.41^{\mathrm{b}} \pm 2.33$ & $11.16^{\mathrm{a}} \pm 2.53$ & $8.81^{\mathrm{b}} \pm 3.28$ & $7.90^{\mathrm{ab}} \pm 1.39$ & $6.84^{\mathrm{c}} \pm 1.81$ & $7.86^{\mathrm{ab}} \pm 2.06$ \\
Days to flowering & $46.43^{\mathrm{ab}} \pm 0.35$ & $42.77^{\mathrm{b}} \pm 2.5$ & $40.67^{\mathrm{c}} \pm 6.09$ & $51.20^{\mathrm{a}} \pm 6.54$ & $47.20^{\mathrm{ab}} \pm 8.89$ & $41.50^{\mathrm{c}} \pm 5.18$ \\
No. of flowers & $21.33^{\mathrm{ab}} \pm 1.76$ & $20.33^{\mathrm{ab}} \pm 1.20$ & $20.67^{\mathrm{ab}} \pm 0.33$ & $21.67^{\mathrm{a}} \pm 0.33$ & $21.00^{\mathrm{ab}} \pm 1.15$ & $21.33^{\mathrm{c}} \pm 0.33$ \\
No of Flower aborted & $5.12^{\mathrm{ab}} \pm 0.15$ & $5.61^{\mathrm{a}} \pm 0.47$ & $5.56^{\mathrm{ab}} \pm 0.34$ & $5.00^{\mathrm{c}} \pm 0.13$ & $5.00^{\mathrm{c}} \pm 0.20$ & $5.00^{\mathrm{c}} \pm 0.02$ \\
No of Fruit aborted & $8.37^{\mathrm{a}} \pm 0.27$ & $8.20^{\mathrm{ab}} \pm 0.82$ & $7.20^{\mathrm{c}} \pm 0.82$ & $8.47^{\mathrm{a}} \pm 0.43$ & $8.42^{\mathrm{a}} \pm 0.25$ & $8.20^{\mathrm{ab}} \pm 0.82$ \\
No. of days to ripening & $6.03^{\mathrm{a}} \pm 0.27$ & $5.93^{\mathrm{b}} \pm 0.27$ & $5.80^{\mathrm{ab}} \pm 0.46$ & $5.97^{\mathrm{a}} \pm 0.39$ & $5.33^{\mathrm{c}} \pm 0.07$ & $5.97^{\mathrm{a}} \pm 0.48$ \\
Fresh Fruit weight, kg & $93.67^{\mathrm{ab}} \pm 5.67$ & $97.10^{\mathrm{a}} \pm 8.33$ & $94.67^{\mathrm{c}} \pm 7.17$ & $88.00^{\mathrm{c}} \pm 1.15$ & $94.67^{\mathrm{a}} \pm 3.84$ & $93.67^{\mathrm{ab}} \pm 3.71$ \\
Fruit weight, kg & $29.00^{\mathrm{ab}} \pm 1.53$ & $28.67^{\mathrm{b}} \pm 1.20$ & $30.00^{\mathrm{a}} \pm 0.00$ & $29.33^{\mathrm{a}} \pm 0.88$ & $28.33^{\mathrm{c}} \pm 0.33$ & $30.00^{\mathrm{a}} \pm 0.58$ \\
No. of days to rotting & $5.93^{\mathrm{b}} \pm 0.23$ & $6.03^{\mathrm{ab}} \pm 0.17$ & $5.70^{\mathrm{c}} \pm 0.42$ & $5.97^{\mathrm{ab}} \pm 0.19$ & $6.20^{\mathrm{a}} \pm 0.20$ & $6.10^{\mathrm{a}} \pm 0.59$ \\
\hline
\end{tabular}

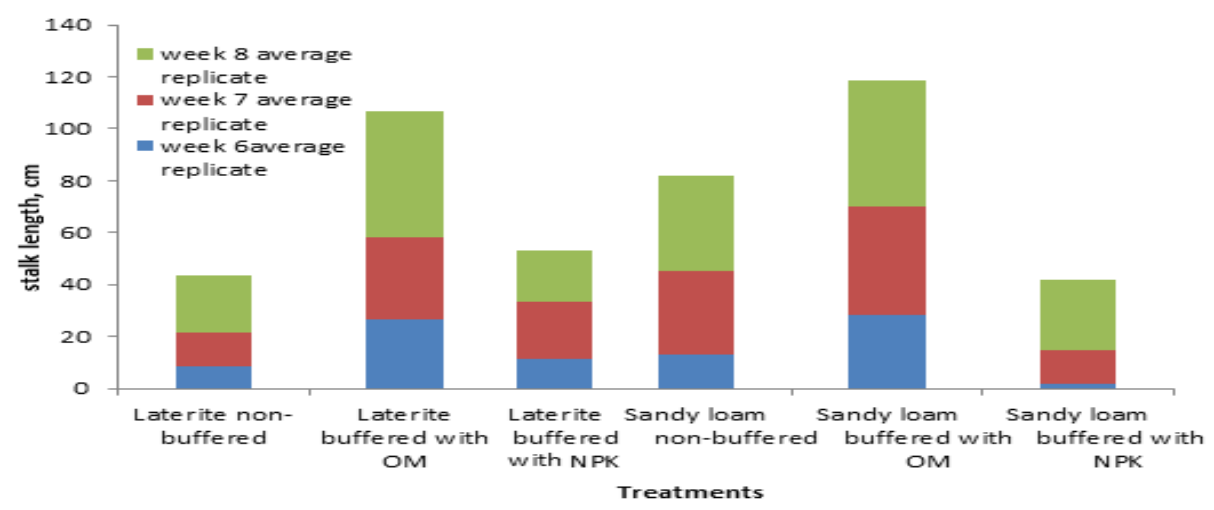

Fig 1: Chart showing growth of vegetative stalk at critical 6th, 7th and 8th weeks

Therefore the effect of the buffering with $\mathrm{OM}$ and NPK were on the crop as their yield parameters were significantly influenced, Table 4 . In all, OM had higher values than NPK in both soil types. The effect of the buffering was also revealed when the nonbuffered mean values of the yield parameters and those buffered were compared, Table 4.

The various treatment applied as well as the various soil conditions significantly differed on all the growth parameters after monitoring for 4, 5 and 6 weeks after planting (WAP).

Similarly, the number of flowers per plant and the total fresh fruit were significantly affected by the soil type and both buffering materials.

Fruit and fruiting parameters: Numbers of flowers per plant of tomato were significantly influenced also by the various treatments across successive replicate, Table 5, Figure 1. Significantly, higher number of flowers were recorded from plants treated with $\mathrm{OM}$ and NPK 15:15:15. While the least number of flowers per plant were experienced in the sandy loam soil.

Conclusion: Lateritic soil if buffered with organic matter could yield as high as the sandy loam soil for the planting of tomatoes. The same lateritic soil when buffered with NPK may not yield more crop per hectare of land when compared to organic matter buffering.

\section{REFERENCES}

Adepetu, JA; Adetunji, MT; Ige, DV (2014). Soil fertility and crop nutrition. Soil organic matter, $p$. 92-96, 109, 440

Agegnehu, G; Lakew, B; Nelson, PN (2014a). Cropping sequence and nitrogen fertilizer effects on the productivity and quality of malting barley and soil fertility in the Ethiopian highlands. Arch. Agron. Soil Sci. 60: 1261-1275.

Anda, M; Shamshuddin, J; Fauziah, CI; Omar, SRS (2008). Mineralogy and factors controlling charge development of three oxisols developed from different parent materials. Geoderma 143 (1-2): 153-167.

Anderson, JM; Ingram, JSI (1993). Tropical Soil Biology and Fertility: A handbook of Methods. Second Edition. CAB International, the Cambrian News, Aberstwyth, United Kingdom. pp.221. 
Bodner, G; Leitner, D; and Kaul, HP (2014). Coarse and fine root plants affects pore size distributions differently. Plant Soil 380: 133-151

Bremner, JM (1996). Total Nitrogen. In: Sparks, DL (ed). Methods of Soil Analysis. Part 3. Chemical Methods. SSA and ASA. Madison, Wisconsin, USA, pp.1123-1184

Chen, G; Well, RR (2010). Penetration of cover crops through compacted soils. Plant soil: 331: 31-43

Chen, YF; Wang, Y; Wu, WH (2008). Membrane transporters for nitrogen, phosphate and potassium uptake in plants. J Integr Plant Biol. 50: 835-848.

CoHort Software, (2014). Statistical Package for analysis.

Cresswell, H; Kirkegaard, J (1995). Subsoil amelioration by plant-roots, the process and the evidence. Soil Res. 33: 221-239

Gee, GW; Or, D (2002). Particle size distribution. In: Dane, JH and Topp, GC (eds). Methods of Soil Analysis. Part 4.Physical Methods .Soil Sci. Am. Book series No.5, ASA and SSSA, Madison, W.I. p. 255-293.

Hendershot, WH; Lalande, H; Duquette, M (1993). Soil reaction and exchangeable acidity. In: Carter, M. R (ed.). Soil sampling and method of soil analysis. Canadian Soc. Soil Sci. Lewis publisher, ondon, p. 141-145.

Ko, TH (2008). Removal of hydrogen sulfur from coal-derived gas by iron oxides in various oxisols. Environ. Engineer. Sci. 25(7): 969-973.

Ko, TH; Chu, H; Lin, HP; Peng, CY (2006). Red soil as a regenerable sorbent for high temperature removal of hydrogen sulfide from coal gas, J. Hazard. Mat. 136 (3): 776-783

Mulatu, B; Lakew, B (2011). Barley research and development in Ethiopia-an overview. In:
Mulatu, B., Grando, E. (Eds.). Barley Research and Development in Ethiopia. ICARDA. Addis Ababa, Ethiopia, 1-18.

Nelson, DW; Sommers, LE (1996). Total carbon, Organic carbon and Organic matter. In: Sparks, D.L. (ed) .Methods of soil analysis. Part 3, SSSA. Book series No 5.SSSA Madison, W.I. p. 9601010.

Quinn J.G (1999). "The Prospect of Commercial Production of Tomato in West Africa". A paper Presented at Agricultural Research Seminar on Tropical Vegetables held at eh Conference Centre Ibadan, Nigeria.

Quinn J.G (2003). "Environment and Establishment for Industrial Tomato Crops in Northern Nigeria". A paper Presented at a meeting of Tomato Working Group of Eucarping International Centre held at Institute of Agricultural Research, Ahmadu Bello University, Zaria, Nigeria.

Shaw, JN (2001). "Iron and aluminium oxide characterization for highly-weathered Alabama ultisols," Communications in Soil Science and Plant Analysis, 32 (1-2): 49-64.

Stirzakerir, RJ; Passioura, JB; Wilms, Y (1996). Soil structure and plant growth: Impact of bulk density and biosphere. Plant soil 185: 151162

Thomas, GW (1982). Exchangeable cations. In: Page, A.L. et al., (eds). Methods of Soil and Analysis. Part 2. Agronomy Monograph, a second edition, ASA and SSSA Madisson. p. 159-165.

Tindall HD (1998). Commercial Vegetable Growing. (Ebenezer Baylis and Son Limited, London) p. 241

Zelleke, G; Agegnehu, G; Abera, D; Rashid, S (2010). Fertilizer and Soil Fertility Potential in Ethiopia: Constraints and Opportunities for Enhancing the System. International Food Policy Research Institute (IFPRI), Washington, DC, USA 